\title{
The relationship between Parental Level of Education and Learners Performance in Public Pre -Primary schools in Nandi County, Kenya

\author{
Mary Jebii Chemagosi*
}

Pwani University, Kilifi County, Kenya

\begin{abstract}
Factors related with parental involvement on their children's education continues to be a pertinent issue. Some school going children in Kenya post detrimental results amid claims that parents are not supportive. This study sought to establish influence of Parental Level of Education on Pre-Primary Learners' performance in curriculum activities in Nandi County, Kenya. Epstein's Theory and descriptive survey design was used for the study. Purposive sampling technique, stratified random technique and simple random technique were used to select the sample of the study. The sample for the study was 50 head teachers 100 teachers and 100 parents in pre-Primary schools from a population of 500 head teachers, 1000 teachers and 10000 parents. Questionnaire, interview guides and focused group discussions were used to collect data. A pilot study was conducted in two schools to determine the validity and reliability of instruments. Both content and face validity were ensured while split half technique was used to determine the instrument's reliability. Quantitative data was analyzed using descriptive such as frequencies and percentages and presented in form of tables while inferential statistics used simple linear regression. Qualitative data was analyzed and presented in narrative form.
\end{abstract}

Keywords: Performance, Influence, Highy educated Parents, Lowly educated Parents, Parental level of education, Pre-Primary school.

\section{Introduction}

Education is the foundation upon which the human social, cultural, economic and political development of any country is founded on (Psacharopoulos, 2013). Basil (2007) posit that the low parental engagement socio-economic status lead to detrimental students' academic performance. The study further reveal that effective parental support and sound economic status result to effective childrens performance.The family background in relation to family size, structure, educational background and socio-economic status play a significant role in the foundation for children's development. Osunloye (2008) noted that home conducive learning environment such as adequate financial resources and time engagement enables childrens' educational achievement and social integration.

OECD and UNESCO (2003) assert that parental occupation and educational achievement has an impact on increased learning opportunities both at school and school. This implies that educated parents contribute to children's education attainment through assistance with homework and provision of teacing and learning materials. In the same vein parents with higher socio-economic income and educational achievement have high aspirations for their childrens carrer and education advancement.

In the USA, substantial evidence of parental involvement in education exists both within the school and at home. According to No Child Left behind Act of 2001 parental participation and engagement is recognized in determining the quality of teaching and learning processes in schools (Education Department, 2004). The National Institutes of Health (2013) further indicate that parent level of education correlates with child's educational attainments and behavioral. Mattison et al., (2014) concur that parents with higher education levels have a higher confidence and expectations of their children's academic abilities. Such parents expect their children to have high attendance level, be disciplined and score high grades. These implies that high parental high expectations motivate their child to improve on their educational outcome. The South Africa Schools Act (Act 84 of 1996) requires all public schools to have elected School Governing Body that 
comprise of the head teacher, teachers, parents, non teaching staff and students (Dubbeldan 2000). In Burundi, education policies require parents to participate towards financial contributions for schools. In Uganda Universal Primary Education policy of 1997 requires parents to take an active role in support of children's learning. In Kenya the Basic Education Act of Kenya (2013) requires parents to be involved in school Boards of Management in order to assess the needs of school with full participation of parents.

\section{Statement of the Problem}

Research studies indicate that parental participation in children's education improves children's classroom engagement in educational performance. Most studies have looked at various factors viewed at different aspects such as parental; marital status, age, socio-economic status, occupation, gender and education. However, though they exist studies on parental level of education and educational performance, there is still a gap in our understanding of the relationsip of parental level of education and pre-primary learners performance. More so, the mechanisms for having knowledge on influence of parental level of education have not been extensively studied. Therefore, this study sought to establish influence of parental level of education on pre-primary learners' performance in public primary schools in Nandi County, Kenya.

\section{Literature Review}

Parents are considered as the first teachers of their children education. This implies that parental level of education influences children academic attainment. Ahmad (2013) posits that children whose parents have low education attain lower test scores in contrast to pupils whose parents have a high education level. This might be attributed to the fact that educated parents provide psychological, economical, emotional and intellectual support to their childrens education than those of illiterate parents. Similarly, children from of educated parents may feel comfortable and adjust to learning process which result in high academic performance.

Desforges and Abouchaar (2003) noted that parental involvement in education of children include: providing a conducive home environment, discussion with the child, role modelling, contact with school, participation in school activities and governments and helping with school homework. Bryan, (2005) adds that children are likely to perform better in a conducive home aenvironment. Haack (2007) noted that less educated parnts are not caring, have poor relationship with their children and assume that its only teachers who have responsibility to guide and counsel students on discipline matters.

According to National Institutes of Health (2013), parental level of education is significantly predicts learner's educational performance and reduced behavioral outcome. Educated parents concentrate in raising children of academic self-perception, involve them in intellectual activities that necessitates positive attitude towards learning with minimal discipline outcome. Further, Guryan, Hurst, Kearney and National Bureau of Economic Research (2008) note that better educated parents spare adequate time with children on educational engagement. This implies that children whose parents are educated acquire and model social skills and problem-solving strategies conducive to their educational attainment. Therefore, children of educated parents exert more interest to learning, have enhanced positive beliefs, are more concerned with education adapts to more learning strategies than children of lower levels of learning.

Kunje (2009) concluded that parental level of education has a positively significant association with learners education aspirations. Vellymalay (2010) conducted a study on the relationship between parents level of education and childrens' attainment. The study revealed that there exist no significant differences between parental level of education and childrens' academic outcome. Ogoye (2007) noted that illiterate parents cannot help their children with homework assignments. Muola (2010) assert that childrens' motivation at their educational attainment largely depends on parental income and level of education.

Rana, Nadeem and Saima (2015) carried out a study on influence of parents' educational level on secondary school students' academic achievements in Rajanpurdistrict, Pakistan. A sample of 200 students was sampled through simple random technique. The inferential statistics, Z-test was used to indicate the relationship between parental level of education and students' academic performance. The study concluded that highly educated parents have a positive influence on children academic outcome. However, the present study was conducted in pre-primary schools and used ANOVA to indicate the relationship between variables under investigation. 
Ahmad and Naeema (2013) posit that parents of good educational background are in a position to act as second teachers, provide necessary learning materials and guiding and counseling their children in educational matters than those of illiterate parents. Echaun, Ndiku and Sang (2015) investigated influence of parental engagement in childrens' homework academic performance in public primary schools in Teso North Sub County, Busia- Kenya. The study concluded that parents assist children in reading, writing and solving problems. Musgrave, (2000) noted that children from a good educated background always prefer to copy the footsteps of their parents therefore work extremely harder in their studies.

A study by Sureehkumar (2012) in Malaysia indicated that educated parents act as home tutors, engage most of their time and resources in their childrens education, cooperate with school on education-related activities with teachers and prepare home learning time table for the children. These have advantages that enable children to academically perform better.

Aqsa, Ilyas, Azam and Abid (2013) conducted a study on impact of parents' education on children's academic performance in Punjab state, Pakistan. The study adopted cluster random sampling technique to select a sample of 394 students from one University. A self-administered questionnaire was utilized to collect data. Descriptive statistics percentages and inferential statistics ANOVA was used to analyse data. The study concluded that parent level of education have a high association on children's performance.

A study by Amuda and Domiya (2016) determined parental level of education as a predictor of students'academic performance among NCE students in Nigeria. The researcher used a sample of 1200 students selected from a population of 13529 students through stratified sampling and simple random techniques. A Proforma developed by the researchers was used to collect data. Data was analysed using descriptive statistics and multiple linear regression analysis. The study concluded that parental level of education do not significantly correlate with students' academic performance. The study recommended that parents should assist their children with practices such as English speaking language and reading and holding frequent discussions with their children on how to improve in their academic studies.

Osei Akodo et.al (2012) conducted a study on the extent to which parents are involved in their children academic performance in Ghana. The study used randomized cluster sampling technique in which 100 schools were selected from eight out of the total ten regions. The study revealed that a majority of parents $(83 \%)$ assisted their children with educational programmes while $17 \%$ of the parents did not assist their in their educational endaviours. Similarly, Guolaung Erlendsdottir (2010) conducted a qualitative survey study in Namibia on the extent of parental involvement in students' education performance. The study used seven parents of students who had attained high grade scores in examinations. The study revealed a positive correlation between parental involvements in their children education. This was consistent with Kosgey (2016) findings who did a study on influence of parental involvement on students' academic performance in Nakuru County, Kenya. The study used ex-post factodesign and stratified random sampling technique to sample 180 students in 6 secondary schools. The researcher established that parental involvement did not significantly influence students' academic performance.

In Pakistan, Suleman,(2012) established that parental level of education has an effect on secondary school students' academic performance. Ruth, et al (2011) in Spain also posits that there was a positive relationship between parental level of education and cognitive performance in Spanish adolescents. McIntosh (2008) in Canada further established that highly educated parents enable their children to be more successful at school. Farooq, et al (2011) in Pakistan also agree that parental level of education had a significant influence on students' overall academic performance especially in Mathematics and English.

A study by Lara-Cinisomo, et al., (2004) among children from sixty-five Los Angeles neighborhoods in USA established that mothers who had not received secondary school education did not provide reading and other learning materials to their children at home because of their inability to effectively visits the library regularly and read stories to them. This is a clear indication that children of low parental level of education are disadvantaged with school homework assistance. However, the present study looked at parental level of education on both parents unlike the reviewed study that only looked at mothers' level of education.

Additionally, studies by Barnett, Carolan, Fitzgerald and Squires (2011) found out that there exist a correlation between parental levels of education and children's readiness for learning. The study further 
established that parents with higher educational levels have a better understanding of what their children needs such as teaching and learning resources necessary to support childrens' readiness for school. This study however, only looked at parental level of education and childrens' readiness while the present study investigated on childrens' academic performance for grade one.

Kingori and Kingori (2018) conducted a study on parental level of education and students' academic performance in secondary schools in Laikipia County, Kenya. The study was based on Festinger's social comparison theory. It employed ex post facto research design. A questionnaire was used to collect data among 375 Form three and four students in 106 public secondary schools through simple random sampling technique. Descriptive statistics were produced using percentages and frequency while inferential statistics $\chi 2$ statistic was used to indicate relationship between variables at .05 alpha level of confidence. The study revealed that parental level of education had a positive influence on students' academic performance. However, the study did not establish a strong relationship between parental level of education and students' performance at (Cramer's $V=.145)$ and statistically insignificant $(\chi 2=21.22 ; d f=15 ; p>.05)$. The study further revealed that parental level of education ( $p>.05)$ increased with students' educational expectations. However, the present study was based on Bronfenbrenner's (1997) theory of human development and both quantitative and qualitative instruments were used to collect data from head teachers, teachers and parents for analysis and interpreyation on pre-primary learners' performance.

Korir and Wambugu (2018) conducted a study on influence of parental level of education and parental income on students' academic performance in public day secondary schools in Kipkelion Sub-county, Kericho County, Kenya. The study had a sample of 210 form four students selected using stratified and simple random sampling techniques based on causal-comparative research design. Questionnaire and document analysis were used to gather information on students' home environment and on mock examination respectively. Data was analyzed based on descriptive and inferential statistics (ANOVA). The study established that the parental level of education had no effect on students' academic attainment. The study recommended that parents should be sensitized on involvement in the education of their children.

Kainuwa and Yusuf (2013) concur that parents of good educational background are in a better position to model positive social skills, problem solving skills, and positive moral values in children in contrast to those of lowly educated parents. Other related studies established a positive relationship between parental level of education and learners academic performance (Onderi, 2014; Makewa, et al, 2012; Ntitika, 2014). This aspect is supported by Ogweno, et al (2014) who found a positive correlation between mothers level of education and students' academic performance. The above mentioned afore are also in consistence with the findings of Muruwei, (2011) and Alokan, (2013) in Nigeria who established that parental level of education greatly influence students' academic performance.

\section{Theoretical Framework}

This study was premised on Epstein's Theory which stipulates that parental involvement illustrate the link between a family-like school and a schoo-like family. Epstein theory proposes that parents needs to work in liason with school if any positive educational outcomes are to be realized. The theory adds that learners performance is based on family-community link via parenting, volunteering, decision-making, learning at home, communication and collaboration with the family and community. The theory further indicate that parents' failure to provide adequate time and resources, effective communication and close monitoring may hinder childrens' educational performance.

\section{Objective of the Study}

To establish the relationship between parental level of education and learners educational performance in public pre -primary schools.

\section{Research hypothesis}

There is no significant difference when parents are categorized as highly educated or lowly educated on learners educational performance in public pre -primary schools.

\section{Methododology}

The study adopted a descriptive survey design which has a combination of both quantititative and qualitative aspect to collect data and analyse data on parental level of education and childrens performance. 
Data on parental level of education was collected using closed ended questionnaire and a follow up interview schedule.

\section{Results And Discussion}

The study sought to establish whether there exists a relationship between parents' level of education on learners educational performance in public pre -primary schools. Descriptive statistics was collected from head twachers, teachers and parents. Data was produced in form of frequencies and percentages and presented in tables. Inferental statistics was analysed by use of t-test to show the relationship between the independent and dependent variables as indicated below.

Table 1: Head teachers and teacher's response on parental involvement and pre-primary childrens' performance.

\begin{tabular}{|c|c|c|c|c|c|c|c|}
\hline \multirow[t]{2}{*}{ Statement } & \multirow[t]{2}{*}{ Respondent } & \multicolumn{2}{|c|}{ Agree } & \multicolumn{2}{|c|}{ Nuetral } & \multicolumn{2}{|c|}{ Disagree } \\
\hline & & $f$ & $\%$ & $\mathrm{f}$ & $\%$ & $\mathrm{f}$ & $\%$ \\
\hline \multirow[t]{2}{*}{$\begin{array}{l}\text { Highly educated parents supervise childrens' } \\
\text { work }\end{array}$} & $\begin{array}{l}\text { Head } \\
\text { teacher }\end{array}$ & 37 & $74 \%$ & 2 & $4 \%$ & 11 & $22 \%$ \\
\hline & Teacher & 61 & $61 \%$ & 3 & $3 \%$ & 36 & $36 \%$ \\
\hline \multirow[t]{2}{*}{$\begin{array}{l}\text { Lowly educated parents supervise childrens' } \\
\text { work }\end{array}$} & $\begin{array}{l}\text { Head } \\
\text { teacher }\end{array}$ & 9 & $18 \%$ & 12 & $24 \%$ & 29 & $58 \%$ \\
\hline & Teacher & 34 & $34 \%$ & 2 & $2 \%$ & 64 & $64 \%$ \\
\hline \multirow[t]{2}{*}{$\begin{array}{l}\text { Highly educated parents guide and counsel } \\
\text { children }\end{array}$} & $\begin{array}{l}\text { Head } \\
\text { teacher }\end{array}$ & 27 & $54 \%$ & 4 & $8 \%$ & 19 & $38 \%$ \\
\hline & Teacher & 45 & $45 \%$ & 14 & $14 \%$ & 41 & $41 \%$ \\
\hline \multirow[t]{2}{*}{$\begin{array}{l}\text { Lowly educated parents guide and counsel } \\
\text { children }\end{array}$} & $\begin{array}{l}\text { Head } \\
\text { teacher }\end{array}$ & 24 & $48 \%$ & 3 & $6 \%$ & 23 & $46 \%$ \\
\hline & Teacher & 51 & $51 \%$ & 4 & $4 \%$ & 45 & $45 \%$ \\
\hline \multirow[t]{2}{*}{$\begin{array}{l}\text { Highly educated parents assist children with } \\
\text { school homework }\end{array}$} & $\begin{array}{l}\text { Head } \\
\text { teacher }\end{array}$ & 41 & & 0 & 0 & 9 & $18 \%$ \\
\hline & Teacher & 79 & $79 \%$ & 6 & $6 \%$ & 15 & $18 \%$ \\
\hline \multirow[t]{2}{*}{$\begin{array}{l}\text { Lowly educated parents assist children with } \\
\text { school homework }\end{array}$} & $\begin{array}{l}\text { Head } \\
\text { teacher }\end{array}$ & 3 & $6 \%$ & 11 & $22 \%$ & 36 & $72 \%$ \\
\hline & Teacher & 17 & $17 \%$ & 29 & $29 \%$ & 54 & $54 \%$ \\
\hline \multirow[t]{2}{*}{$\begin{array}{l}\text { Highly educated parents provide children with } \\
\text { instructional materials }\end{array}$} & $\begin{array}{l}\text { Head } \\
\text { teacher }\end{array}$ & 27 & $54 \%$ & 0 & 0 & 23 & $46 \%$ \\
\hline & Teacher & 46 & $46 \%$ & 11 & $11 \%$ & 43 & $43 \%$ \\
\hline \multirow[t]{2}{*}{$\begin{array}{l}\text { Lowly educated parents provide children with } \\
\text { instructional materials }\end{array}$} & $\begin{array}{l}\text { Head } \\
\text { teacher }\end{array}$ & 13 & $26 \%$ & 2 & $4 \%$ & 35 & $70 \%$ \\
\hline & Teacher & 37 & $37 \%$ & 13 & $13 \%$ & 50 & $50 \%$ \\
\hline \multirow[t]{2}{*}{$\begin{array}{l}\text { Highly educated parents provide home tutoring to } \\
\text { children }\end{array}$} & $\begin{array}{l}\text { Head } \\
\text { teacher }\end{array}$ & 36 & $72 \%$ & 4 & $8 \%$ & 10 & $20 \%$ \\
\hline & Teacher & 64 & $64 \%$ & 15 & $15 \%$ & 21 & $21 \%$ \\
\hline $\begin{array}{l}\text { Lowly educated parents provide home tutoring to } \\
\text { children }\end{array}$ & $\begin{array}{l}\text { Head } \\
\text { teacher }\end{array}$ & 28 & $56 \%$ & 5 & $10 \% 12 \%$ & 17 & $34 \%$ \\
\hline
\end{tabular}




\begin{tabular}{|c|c|c|c|c|c|c|c|}
\hline & Teacher & 53 & $53 \%$ & 12 & & 35 & $35 \%$ \\
\hline \multirow[t]{2}{*}{$\begin{array}{l}\text { Highly educated parents assist in modelling } \\
\text { children behaviour }\end{array}$} & $\begin{array}{l}\text { Head } \\
\text { teacher }\end{array}$ & 41 & $82 \%$ & 1 & & 8 & $16 \%$ \\
\hline & Teacher & 59 & $59 \%$ & 14 & $14 \%$ & 27 & $27 \%$ \\
\hline \multirow[t]{2}{*}{$\begin{array}{l}\text { Lowly educated parents assist in modelling } \\
\text { children behaviour }\end{array}$} & $\begin{array}{l}\text { Head } \\
\text { teacher }\end{array}$ & 29 & $58 \%$ & 3 & & 18 & $36 \%$ \\
\hline & Teacher & 39 & $39 \%$ & 10 & $10 \%$ & 51 & $51 \%$ \\
\hline \multirow[t]{2}{*}{$\begin{array}{l}\text { Highly educated parents provide children with } \\
\text { homework timetable }\end{array}$} & $\begin{array}{l}\text { Head } \\
\text { teacher }\end{array}$ & 45 & & 4 & & 1 & \\
\hline & Teacher & 38 & $38 \%$ & 30 & $35 \%$ & 32 & $38 \%$ \\
\hline \multirow[t]{2}{*}{$\begin{array}{l}\text { Lowly educated parents provide children with } \\
\text { homework timetable }\end{array}$} & $\begin{array}{l}\text { Head } \\
\text { teacher }\end{array}$ & & $16 \%$ & & & 41 & $82 \%$ \\
\hline & Teacher & 27 & $27 \%$ & 13 & $13 \%$ & 60 & $60 \%$ \\
\hline \multirow[t]{2}{*}{$\begin{array}{l}\text { Highly educated parents provide children with } \\
\text { adequate time for reading }\end{array}$} & $\begin{array}{l}\text { Head } \\
\text { teacher }\end{array}$ & 35 & & & & 12 & \\
\hline & Teacher & 29 & $29 \%$ & 19 & $19 \%$ & 52 & $52 \%$ \\
\hline \multirow[t]{2}{*}{$\begin{array}{l}\text { Lowly educated parents provide children with } \\
\text { adequate time for reading }\end{array}$} & $\begin{array}{l}\text { Head } \\
\text { teacher }\end{array}$ & 17 & $34 \%$ & & & 31 & $62 \%$ \\
\hline & Teacher & 33 & $33 \%$ & 43 & $43 \%$ & 24 & $24 \%$ \\
\hline \multirow[t]{2}{*}{$\begin{array}{l}\text { Highly educated parents attend and deliberate to } \\
\text { school meetings }\end{array}$} & $\begin{array}{l}\text { Head } \\
\text { teacher }\end{array}$ & 34 & $68 \%$ & 0 & $0 \%$ & 16 & $32 \%$ \\
\hline & Teacher & 50 & $50 \%$ & 21 & $21 \%$ & 29 & $29 \%$ \\
\hline \multirow[t]{2}{*}{$\begin{array}{l}\text { Lowly educated parents attend and deliberate to } \\
\text { school meetings }\end{array}$} & $\begin{array}{l}\text { Head } \\
\text { teacher }\end{array}$ & 25 & $50 \%$ & 0 & $0 \%$ & 25 & $50 \%$ \\
\hline & Teacher & 51 & $51 \%$ & 11 & $11 \%$ & 38 & $38 \%$ \\
\hline
\end{tabular}

The table indicate that a majority of head teachers 37(74\%) and teachers $61(61 \%)$ agree that educated parents help their children with supervision of school academic work while another majority of head teachers $29(58 \%)$ and teachers $64(64 \%)$ disagree that lowly educated parents help their children with supervision of work. The results indicate that highly educated parents are competent enough to help their children with school matters such as arrival and departure time and ensuring they home study timetable. Mattison Mattison and Blumenfield (2014) concurs that parents with higher education levels have a higher confidence and expectations of their children's academic abilities and expect their children to have high attendance level, be disciplined and score high grades.

The table indicate that majority of head teachers $27(54 \%)$ agree and $19(38 \%)$ disagree that highly educated parents assist children with guidance and counseling. The teachers response shows that majority $51(51 \%)$ agree and $45(45 \%)$ disagree with the statement. Another $4(8 \%)$ of head teachers and $14(14 \%)$ of teachers were non-commital to the statement. Further, majority of head teachers 24 (48\%) agree and $23(46 \%)$ disageree that lowly educated parents assist children with guidance and counseling. Only $51(51 \%)$ of teachers agree and $45(45 \%)$ disahgree that lowly educated parents assist children with guidance and counseling. Only 4 (4\%) of teachers were neutral. The resuts imply that lowly educated parents are less interested in learners discipline and guiding and counseling because they have limited knowledge in educational matters unlike highly educated parents. Ahmad (2013) concurs that parents with high educational background are in a position to provide guiding and counseling to their children with educational matters than those of less edcated parents. Haack (2007) noted that lowly educated parents are 
not caring, have poor inter-personal relationship wth their children and consider teachers as the only persons responsible for providing guiding and counseling to students on discipline matters.

On homework, the results shows that highly educated parents assist their children with completion of school homework assignments because majority $41(82 \%)$ agree while $9(18 \%)$ disagree with the statement. From teachers response, $79(79 \%)$ agree while $18(18 \%)$ disagree and $3(3 \%)$ are neutral with the statement. Similarly, head teachers $3(6 \%)$ agree, $11(22 \%)$ disagree and $36(72 \%)$ are neutral that parents with low educational background assist their children with completion of school homework assignments. Teachers also agree that parents with low educational background assist their children with completion of school homework assignments as indicated by $17(17 \%), 29(29 \%)$ neutral and $54(54 \%)$ disagree with the statement. The results reveals that highly educated parents are competent enough to guide ansd assit children with homework assignments unlike illiterate parents who cannot be able to read and write to their children. Ogoye (2007) is in agreement that illiterate parents cannot help their children with homework assignments. Muola (2010) also noted that childrens' motivation at their educational attainment largely depends on parental income and level of education.

Evidence from the table shows that majority of head teachers $27(54 \%)$ agree and $23(46 \%)$ disagree that highly educated parents provide instructional materials to the children. A large proportion of teachers 46 (46\%) agree and $43(43 \%)$ disagree that highly educated parents provide instructional materials to their children. Only $13(26 \%)$ of teachers were undecided. Another large proportion of head teachers $35(70 \%)$ disagree and $13(26 \%)$ agree that lowly educated parents provide instructional materials to their children. The results were similar to a majority of teachers $50(50 \%)$ disagree and $37(37 \%)$ agree that lowly educated parents provide instructional materials to their children. This means that most lowly educated parents lacked knowledge on the best materials to provide for effective teaching materials to their children unlike the highly educated parents. Barnett, Carolan, Fitzgerald and Squires (2011) concur that parents with higher educational levels have a better understanding of what their children needs such as teaching and learning resources necessary to support childrens' readiness for school.

It is evidence from the table that a large proportion of head teachers $36(72 \%)$ agree and $10(20 \%)$ disagree that highly educated parents provide home tutoring to their children. This is supported by teachers $64(64 \%)$ who agree and $21(42 \%)$ disagree with the statement. Only $4(8 \%)$ of head teachers and $15(15 \%)$ of teacchers were neutral on the response. Most head teachers $28(56 \%)$ agree and $17(34 \%)$ disagree that lowly educated parents provide home tutoring to their children. This large number $53(53 \%)$ agree and $35(35 \%)$ disagree with the statement. Only 5 (10) of head teachers and $12(12 \%)$ of teachers were undecided. Educated parents have knowledge on how to assist children with reading, writing and comprehending answers on their childrens' homework in contrast with those of lowly educated parents. Ahmad and Naeema (2013) are in agreement that parents of good educational background are in a position to act as second teachers to their children in educational matters than those of illiterate parents. Echaun, Ndiku and Sang (2015) noted that parental engagement in childrens' homework completion include reading, writing and solving problems.

The table shows majority of head teachers $45(90 \%)$ agree and $1(2 \%)$ disagree that highly educated parents provide children with home reding timetable. Majority teachers $38(38 \%)$ agree and $32(32 \%)$ disagree with the statement. On contrary, majority head teachers $41(82 \%)$ disagree and $8(16 \%)$ agree that lowly educated parents provide children with home reding timetable. Simlar majority teachers $60(60 \%)$ disagree and 27 (27\%) agree that lowly educated parents provide children with home reding timetable. This means that highly educated parents have knowledge on how to limit childrens relaxation by employing extra school timetable personnel on school educational performance unlike lowly educated parents. Sureehkumar (2012) noted that educated parents cooperate with school on education-related activities with teachers and prepare home learning time table for the children.

The table indicate majority head teachers $34(68 \%)$ and teachers $50(50 \%)$ agree that highly educated parents attend to school meetings. Another proportion of head teachers $16(32 \%)$ and teachers $29(58 \%)$ disagree with the statement. Another majority head teacher $25(50 \%)$ and teachers $51(51 \%)$ agree that lowly educated parents attend to school meetings. Another proportion of head teachers $25(50 \%)$ and teachers 38 (38\%) disagree with the statement. It is evidence from respondents response that both highly and lowly 
educated attend to meetings summoned by the school to deliberate on educational matters concerning children. The results are consistence with Vellymalay (2010) who revealed that there exist no significant differences between parental level of education and childrens' academic outcome.

The results from the table shows a large proportion of head teachers $41(82 \%)$ and teachers $59(59 \%)$ are in agreement that highly educated parents assist in modelling children behavior. Only $8(16 \%)$ of head teachers and 27 (27\%) disagree with the statement. Another large number of head teacher 29 (58\%) and 39 (39\%) also agree that lowly educated parents assist in modelling children behavior. This implies that higly educated parents have resources to model chidrens' behavior unlike lowly educated parents. Kainuwa and Yusuf (2013) concur that parents of good educational background are in a better position to model positive social skills, problem solving skills, and positive moral values in children in contrast to those of lowly educated parents.

This result was corroborated by qualitative data from the interview of parents. Majority of the parents with higher levels of education noted that they took an active role in children's learning. Here is what one of the parents had to say;

"I am aware that I have to play an active role in my child's education if he has to succeed. I normally help him with homework and where am not sure, I always call the class teacher for more guidance. I normally supervise my son while doing homework, provide him with home study timetable and learning materials indicated by the teacher in the diary. I sometimes offer tutorial studies but also seek services of a qualified trained teacher." [........ a highly educated parent]

Anther lowly educated parent had this to say;

\section{"I cannot assist my children with homework or even guide them on educational matters because it is the teachers responsibility. [..... a lowly educated parent]}

\section{Simple Regression}

To determine whether independent variables affect the dependent variable, multiple regressions were used. To achieve this, learner's performance in public pre-primary schools as the dependent variable was regressed against parental level of education. This section examined whether the simple regression equation can be used to explain the influence of parental level of education on learners' performance in public preprimary schools.

\section{Table 2: Model summary}

\begin{tabular}{|c|c|c|c|c|}
\hline Model & R & R Square & Adjusted R Square & $\begin{array}{c}\text { Std. Error of the } \\
\text { Estimate }\end{array}$ \\
\hline 1 & $.621^{\mathrm{a}}$ & .386 & .380 & .56860 \\
\hline
\end{tabular}

\section{a. Predictors: (Constant), Parental level of education}

From the results obtained, an $\mathrm{R}$ of 0.621 shows that there is a positive correlation between parental level of education and learners performance.

The adjusted $\mathrm{R}$ square of 0.380 indicates that parental level of education in exclusion of the constant variable explained the change in learners performance by $38 \%$, the remaining percentage can be explained by factors not included in the model.

The coefficient of determination (r-squared) of 0.386 indicates that $38.6 \%$ of learners performance can be explained by parental level of education. The findings on ANOVA results on parental level of education and learners performance are presented in Table 3.

Table 3: ANOVA results

\begin{tabular}{|l|l|c|c|c|c|c|}
\hline \multicolumn{2}{|c|}{ Model } & $\begin{array}{c}\text { Sum of } \\
\text { Squares }\end{array}$ & df & $\begin{array}{c}\text { Mean } \\
\text { Square }\end{array}$ & F & Sig. \\
\hline 1 & Regression & 85.206 & 4 & 21.302 & 38.591 & $.000^{\mathrm{b}}$ \\
\hline
\end{tabular}




\begin{tabular}{|l|l|l|l|l|l|l|}
\hline & Residual & 135.787 & 246 & .552 & & \\
\cline { 2 - 7 } & Total & 220.993 & 250 & & & \\
\hline
\end{tabular}

\section{a. Dependent Variable: Learners performance}

\section{b. Predictor: (Constant), Parental level of education}

The Analysis of Variance (ANOVA) indicated a p-value of 0.000 . This, therefore, means that the relationship between parental level of education and learners performance was significant at $95 \%$ confidence level. The F statistics of 38.591 was large enough to conclude that the variable has a significant influence on learners performance in public pre primary schools in Nandi County, Kenya.

This implies that $\mathrm{X}_{1}=$ Parental level of education, are significant predictors at explaining learners performance and that the model is significantly fit at $95 \%$ confidence level.

\section{Table 4: Model coefficients}

\begin{tabular}{|c|c|c|c|c|c|c|}
\hline \multirow{2}{*}{\multicolumn{2}{|c|}{ Model }} & \multicolumn{2}{|c|}{$\begin{array}{c}\text { Unstandardized } \\
\text { Coefficients }\end{array}$} & \multirow{2}{*}{$\begin{array}{c}\begin{array}{c}\text { Standardize } \\
\text { d } \\
\text { Coefficients }\end{array} \\
\\
\text { Beta } \\
\end{array}$} & \multirow[b]{2}{*}{$\mathbf{t}$} & \multirow{3}{*}{$\begin{array}{l}\text { Sig. } \\
.000\end{array}$} \\
\hline & & B & $\begin{array}{c}\text { Std. } \\
\text { Error }\end{array}$ & & & \\
\hline \multirow[t]{2}{*}{1} & (Constant) & 1.653 & .129 & & 12.835 & \\
\hline & Parental level of education & .140 & .047 & .186 & 2.994 & .003 \\
\hline
\end{tabular}

a. Dependent Variable: Learners performance

Further analysis as shown in Table 4 shows that parental level of education had a coefficient of 0.140 . From the coefficients, the model developed was as follows;

Learners performance $=1.653+0.140$ Parental level of education .

The beta Coefficient shows that parental level of education was statistically significant with positive beta coefficients.

\section{Conclusion}

It can be concluded that parental level of education influence learners performance in public pre -primary schools in Nandi County, Kenya as shown by a p value of 0.003 .

\section{Recommendation}

The results of this study imply that there is need to conduct parents training in order to help parents effectively parent their children. This need stems from the realization that some parents cannot effectively assist children with matters concerning education. There are increased roles of parents in facilitating learning particularly in the pre-primary level of education. The Government of Kenya should strengthen Adult Euducation in all counties to eradicate illiteracy level among parents. The government of Kenya should extend the Free Primary Education to pre-primary sector by providing teaching and learning materials in order to crter for children from lowly educated parental background.

\section{Reference}

[1.] Ahmad, K. \& Naeema, B. (2013). Influence of socioeconomic and educational Background of parents on their children' education in Nigeria. International journal of scientific and research publications, volume 3.

[2.] Alokan, B. F, Osakinle, E. O, \& Onijingin, E.O. (2013).The influence of parents educationalbackground and study facilities on academic performance amongsecondary school students. Ozean Journal of Social Sciences Vol 6 (2).

[3.] Amuda, B.G. \& Domiya, G.A (2016).Parents' level of education as predictors of academic performance of Nce students of colleges of education in the North- Eastern States of Nigeria.IOSR Journal of Humanities and Social Science Vol 21, (2) pp. 41-47 
[4.] Aqsa, S., Ilyas, M., Azam, R.,\& Abid, H. (2013). Impact of Parents' Education on Children's Academic Performance. Secondary Education Journal Volume 2, No. 1 pp. 53-59

[5.] Basil, A.O (2007). Socio- Economic factors influencing students' Academic Performance in Nigeria-in ido local Government Area of Oyo. Free online library.

[6.] Bryan, J.B. (2005). Fostering educational resilience and achievement in urban schools through School-family-community partnerships. Professional school of counseling, 8,219 227.

[7.] Desforges, C. \& Abouchaar, A. (2003). The impact of parental involvement, parental support and family education on pupil achievement and adjustment: A literature review. Research Report, no. 433. Queen's Printer, No.33.

[8.] Dubbeldan, L.F.B. (2000). The primary school and the community in Mwanza district, Wolters Noordhoff publishing. Groningen.

[9.] Echaun, M., Ndiku, M.J., \& Sang,A. (2015). Parental Involvement in Homework and Primary School Academic Performance in Kenya. Journal of Education and Practice Vol.6, No.9 pp. $46-53$

[10.] Education department. (2004). Parental Involvement: Title 4. Non - regulatory guidance. No Child Left Behind. USA.

[11.] Farooq, M. S, Chaudhry, A. H., Shafiq, M., and Berhanu, G, (2011). Factors Affecting Students Quality ofAcademic Performance: A case of Secondary School Level. Journal of Quality and TechnologyManagement Volume VII (Issue II)

[12.] Guolang, E. (2010). Effects of parental involvement in education: A case study of Namibia. (Masters' thesis) University of Iceland.

[13.] Guryan, J., Hurst, E., Kearney, M. S., \& National Bureau of Economic Research.(2008). Parental education and parental time with children. Cambridge, Mass: National Bureau of Economic Research.

[14.] Haack, (2007). Parents and Teacher beliefs about parental involvement in schooling. (Unpublished, $\mathrm{PhD}$ Theses) University of Neburska-Lincon. Open access theses and dissertation from the college of education and human sciences, Paper 12.

[15.] Kainuwa, A., \& Yusuf, M. B. (2013). Students' perspective on female dropouts in Nigeria. International Journal of Academic Research in Education and Review. Vol. 1 (2) pp. 29-37.

[16.] King'ori, E., W, \&King'ori, I.W. (2018) Parental level of Education and Students' Academic Ambition-A case study of Secondary Schools in Laikipia County, Kenya.East African Scholars Multidisciplinary BulletinVolume 1(1) pp. 34-40

[17.] Kosgey, B.K. (2016) Influence of parental involvement on students' academic performance of public mixed day secondary schools in Kuresoi Sub-County, Nakuru County, Kenya.International Journal of Education and Research Vol. 2 No. 12International Journal of Education and Research Vol. 2 No. 12pp. 505-516

[18.] Kunje , D.(2009). An Investigation of the Relationship between school and pupil characteristics and achievement at the Basic Education Level in Malawi.

[19.] Makewa, L. N, Role, E, and Otewa, F. (2012). Parental Factors Affecting Academic Achievement of Grade Six Pupils in Kisumu City, Kenya. International Journal of Asian Social Science2(11):1984-1997.

[20.] Mattison, S. M., Scelza, B., \& Blumenfield, T. (September 01, 2014). Paternal Investment and the Positive Effects of Fathers among the Matrilineal Mosuo of Southwest China.American Anthropologist, 116, 3, 591-610.

[21.] Muola, H. (2010). A study of the relationship between academic achievement motivation and home environment among standard eight pupils Educational Research and Reviews Vol. 5(5), pp. 2013 2017, May, 2010 ISSN 1990 - 3839 @ 2010 Academic Journals.

[22.] Muruwei, M. (2011). Parents' Level of Education and Senior Secondary Students' Academic Performance in English Language. In Bayelsa State, Nigeria.Ntitika, J. L. (2014).Parental Characteristics Influencing Students' Academic Performance in Public Secondary Schools, In IsinyaDistrict, Kenya. Unpublished M. Phil. University of Nairobi.

[23.] OECD/UNESCO. (2003) Family Background and Literacy Performance.

http://www.oecd.org/dataoecd/43/9/33690591.pdf. 
[24.] Onderi, H, Kiplangat, R.K, and Awino, J, (2014). FactorsContributing to Poor Academic Performance in Kenya Certificate of Secondary Education in Public Secondary Schools in Kericho Sub - County, Kericho County, Kenya. Kenya Journal ofEducational Planning, Economics \& Management (2014) Volume 7, Issue 2.

[25.] Ogoye, H (2007). Parental participation in pupil homework in kenya :Insearch of an inclusive policy Nairobi: Act press.

[26.] Osei-Akoto, I., Chowa, G. and Ansong, D. (2012) Parental involvement and academic performance in Ghana. Youth save Research Brief, CSD publication No. 12-42.

[27.] Osunloye, A. (2008). Family Background and Student Academic Performance.Retrieved from;http://socyberty.com/education/family-background-student academic performance.

[28.] Psacharopoulos, G. (2013). The value of investment in education: Theory, evidence and policy. Journal of Education Finance, Vol. 32, No. 2, O’Leary Issue. 2006, pp. 113-136.

[29.] The Basic Education Act (2013). Government of Kenya printers. Nairobi. Kenya.Ruth, C; Jonatan, R; Palma, C; David, J; Ligia, D.E; Moreno, L.A, and Ortega,

[30.] B.F.(2011).Associations between parental educational/occupational levels and cognitive performance in Spanish adolescents: The AVENA study Psicothema.Vol. 23. pp. 349-355.

[31.] Suleman, Q; Aslam, H. D; Hussain, I; Shakir, M; Khan, F, U; and Nisa, Z. (2012).Effects of Parental Socioeconomic Status on the Academic Achievement of Secondary School Students in Karak District, Pakistan International Journal of Human Resource Studies ISSN 2162-3058 2012, Vol. 2, No. 4

[32.] Sureehkumar, N.V. (2012). The impact of parents' socioeconomic status on parental involvement at home; A case study on high achievement Indian students of a Tamil school in Malaysia, international journal of academic research in business \& social sciences, Vol.2. No.8.

[33.] Vellymalay, S.K.N. (2010). Parental involvement in children's education: Does parents' education level really matters? European Journal of social sciences, 16(3), 430-431.

[34.] World Bank Group (2012). World development indicators 2012. Washington, DC: World Bank.

[35.] Rana, M.A.K., Nadeem, I \& Saima, T. (2015). The influence of Parents Educational level on Secondary School Students Academic achievements in District Rajanpur.Journal of Education and Practice Vol.6, No.16, 2015 PP 76-80.

[36.] Zhang, C. (2011).Parental Education, Family Income, and Peer Group on Children's Academic Performance in China. Bachelor of Social Sciences - Senior Theses. Paper 1. 